\title{
HACIA UNA LECTURA ESCÉNICA DE DIARIO DE UNA ENFERMERA DE ISLA CORREYERO ${ }^{1}$
}

\section{TOWARDS A SCENIC READING OF DIARIO DE UNA ENFERMERA BY ISLA CORREYERO.}

\author{
Pedro Aldunate \\ Universidad Austral de Chile, Chile \\ pedroaldunate@gmail.com
}

\begin{abstract}
Resumen:
En el presente artículo se propone una lectura escénica del libro Diario de una enfermera de la española Isla Correyero, es decir, se sitúan y describen escenas y situaciones dramáticas paradigmáticas, presentes en el texto, las cuales se refieren especialmente a la experiencia de la muerte propia y de la muerte del otro. Como punto de entrada al conjunto de poemas, se destaca la hibridación del género lírico-poético con el discurso autobiográfico y memorialístico. A su vez, se sugieren posibles diálogos y relaciones intertextuales preliminares con Diario de muerte de Enrique Lihn y Veneno de escorpión azul de Gonzalo Millán.
\end{abstract}

Palabras claves: muerte; poesía; diario; Isla Correyero.

\begin{abstract}
:
This article proposes a scenic reading of the book Diario de una enfermera written by the Spanish author Isla Correyero, i.e. the paradigmatic scenes in the text are located and described, which especially refer to the experience of one's own death and the death of the other. As a starting point to the set of poems, the hybridization of the lyricpoetic genre with autobiographical and memorialistic speech is highlighted. At the same time, possible dialogues and preliminary intertextual relations with Diario de Muerte by Enrique Lihn y Veneno de escorpión azul by Gonzalo Millán are suggested.
\end{abstract}

Keywords: death; poetry; diary; Isla Correyero.

Recibido: 06 de octubre de 2019

Aprobado: 21 de noviembre de 2019

\section{Preludio}

El libro Diario de una enfermera (1996), de la poeta española Isla Correyero², se presenta como un diario compuesto de una serie de poemas, algunos titulados y otros

\footnotetext{
${ }^{1}$ Este artículo fue escrito en el marco de la Investigación Postdoctoral: "Poesía chilena y española a partir de 1960: nombres, figuras y escenografías de la muerte", realizado en la Universidad Complutense de Madrid con el beneficio de la Beca Chile de Postdoctorado en el Extranjero, durante 2013 y 2015. Agradezco, muy especialmente, a Niall Binns por su atenta lectura y agudas sugerencias.

${ }^{2}$ Isla Correyero (España, Cáceres, 1957): poeta, enfermera, guionista de cine y televisión; perteneciente a la generación de los “postnovísimos" (o de los años 80'). Ha publicado, entre otros, los siguientes textos:
} 
no, los cuales, en conjunto, se aproximan en el plano formal a la prosa poética. El texto, que fue concebido a la manera de un diario de vida, va señalando de modo explícito la fecha y el lugar de su enunciación ${ }^{3}$. El diario de Isla Correyero registra escrituras fechadas entre el 28 de septiembre de 1993 y el 8 de junio de 1996, las cuales corresponden, aparentemente, a las vivencias personales e íntimas de la escritora, durante su labor de enfermera en diversas clínicas de España. La obra transita entre el diario y la poesía, siendo el texto en su totalidad una coherente unidad de sentido, temporal y espacial, lo cual permitiría leer esta serie de poemas desde una perspectiva escénica y teatral. En este aspecto, visualizar el libro como escena -con sus diversas unidades escénicas y/o poéticas-implica no sólo ver de qué modo la experiencia real, personal e íntima, se traslada al texto, sino también, y muy desgarradoramente aquí, cómo se traspasa la visión de un mundo o escenario a través de la mirada de un sujeto poético, escenario que corresponde al "espacio fantasma” de la clínica.

El objetivo principal de este trabajo es, entonces, establecer una lectura escénica del libro Diario de una enfermera de Isla Correyero, lo cual significa instalar, más que una interpretación, un diálogo con el texto que al mismo tiempo sea un desplazamiento por sus lugares o espacios y por las escenas situadas en ellos ${ }^{4}$. Además de ello, me propongo establecer diálogos y/o relaciones intertextuales entre el diario de Correyero y dos libros en los cuales se registran, quizás, algunas de las experiencias más vertiginosas de escritura sobre y hasta la muerte en la historia de la literatura chilena:

Cráter (1984), Lianas (1988), Crímenes (1993), Diario de una enfermera (1996), Género humano (2014) y, más recientemente, la antología Mi bien (2018), de la Colección Visor de Poesía.

${ }^{3}$ Utilizo aquí la primera edición de 1996, en donde los textos aparecen distribuidos en cuatro secciones: "Diario de una enfermera", "Los párpados azules", "Terminales" y "Muertos, sombras", y por la cual la autora recibió el IV Premio de Poesía Cuidad de Córdoba "Ricardo Molina". Una nueva versión del texto, más ampliada, se encuentra en el libro Género humano publicado por la autora en 2014, el cual introduce importantes cambios en el orden, las fechas y, muy especialmente, en los títulos de los poemas, los cuales han sido reemplazados en su totalidad por las aparentes fechas de redacción de los textos. Lo anterior permitiría señalar que una vez transcurrido el tiempo, entre una y otra versión, la mirada retrospectiva, más próxima al género memorialístico, ofrece la posibilidad de reescribir le experiencia registrada en el diario de vida.

${ }^{4}$ En plena sintonía con una lectura escénica de la obra literaria, es pertinente considerar lo señalado por Susan Sontag al final de su clásico ensayo Contra la interpretación del año 1966: "Lo que ahora importa es recuperar nuestros sentidos, debemos aprender a ver más, a oír más, a sentir más. Nuestra misión no consiste en percibir en una obra de arte la mayor cantidad posible de contenido, y menos aún en exprimir de la obra de arte un contenido mayor que el ya existente. Nuestra misión consiste en reducir el contenido de modo de poder ver en detalle el objeto. La finalidad de todo comentario sobre el arte debiera ser hoy el hacer que las obras de arte -y, por analogía, nuestra experiencia personal- fueran para nosotros más, y no menos, reales. La función de la crítica debiera consistir en mostrar cómo es lo que es, inclusive qué es lo que es y no en mostrar qué significa". En suma, concluye Sontag: "En lugar de una hermenéutica, necesitamos una erótica del arte" (1984: 27). 
Diario de muerte (1989) de Enrique Lihn $^{5}$ y Veneno de escorpión azul (2007) de Gonzalo Millán6, ambos publicados póstumamente; todo ello en vista de que, al observar comparadamente estos textos, estamos en presencia de escenas situadas, de manera ejemplar, en el problema ético y estético de la muerte, aquí ya no solamente entendida como tema o tópico literario; una muerte vivida y observada en el propio cuerpo (Enrique Lihn y Gonzalo Millán), pero también, y de modo específico, en el cuerpo sufriente del enfermo o enferma que se aproxima a morir y muere, ante los atribulados ojos de la enfermera (Isla Correyero).

Tulio Mendoza Belio, en su nota "Isla Correyero: la deslumbradora oscuridad de la desesperación", publicada en el diario El Sur del 5 de octubre de 2014, es quien, en primer lugar, establece algunas relaciones entre los tres textos que aquí me ocupan. Me interesa situar esta nota como primer punto de referencia crítica respecto de la relación entre Correyero, Millán y Lihn, muy especialmente, en lo que respecta a leer estos textos desde la noción de "poesía situada", entendiendo con ello, y de modo específico aquí, que la condición situada de la escritura se lleva al extremo en estos textos

\footnotetext{
${ }^{5}$ Enrique Lihn (Santiago, 1929-1988): poeta y escritor multifacético, una de las figuras más destacadas de la generación del 50'. Publicó más de una veintena de libros de poesía, entre los que destacan: La pieza oscura (1963), Poesía de paso (1966), La musiquilla de las pobres esferas (1969), París, situación irregular (1977), A partir de Manhattan (1979), Al bello aparecer de este lucero (1983), entre muchos otros. Además de ello, publicó diversos ensayos, cuentos y novelas; y también tuvo un interés particular por el teatro y las artes plásticas. Enrique Lihn murió el 10 de julio de 1988, en su departamento de calle Passy 061, en Santiago de Chile, a causa de un cáncer pulmonar (la misma causa de muerte de Gonzalo Millán), pero se mantuvo escribiendo - estoicamente, se ha dicho- casi hasta los últimos días de su muerte. Se trata de una escritura situada, de manera enfática, en la circunstancia de la enfermedad y la muerte. Cabe mencionar aquí que Enrique Lihn, siendo una de las figuras más autorizadas e influyentes de la poesía chilena contemporánea (1950 en adelante) no recibió el Premio Nacional de Literatura. Por su obra Poesía de paso recibió, en 1966, el prestigioso premio Casa de las Américas de Cuba.

${ }^{6}$ Gonzalo Millán (Santiago, 1947-2006): poeta, una de las figuras más importantes y singulares de la generación del 60'. Publicó diversos libros de poesía, entre los que sobresalen: Relación personal (1968), La ciudad (1979), Vida (1984), Seudónimos de la muerte (1984), Virus (1987), Trece lunas (1997), Claroscuro (2002) Autorretrato de memoria (2005), Veneno de escorpión azul. Diario de vida y muerte (2007), entre otros. Recibió diversas distinciones como el Premio Pablo Neruda en 1987 y el Premio Altazor de ensayo por Veneno de escorpión azul. El libro Veneno de escorpión azul es el resultado de una escritura situada, en el sentido planteado por Enrique Lihn, es decir, de un texto poético y autobiográfico que solo se puede decodificar a partir de las circunstancias de su enunciación, esto es, de la enfermedad y la inminencia de la muerte. En este contexto, la noticia del cáncer, ese fatídico 18 de mayo de 2006, llevó al poeta Gonzalo Millán a la escritura de uno de los diarios poéticos más lúcidos y desgarradores de la literatura nacional: una escritura que surge como una necesidad de resistencia, una búsqueda de salud y un modo de asimilar el propio duelo sobre la muerte propia. Al respecto, señala el sujeto: "Escribir Veneno de escorpión azul es hacer algo antes de morir; luchar por tu vida" (Millán, 2007: 40). Y luego agrega: "No me haré tratamiento de rayos ni quimioterapia. Estoy apostando al veneno de escorpión azul", y se refiere también aquí a la escritura, tarea ineludible contra la enfermedad y la muerte, ¿para qué?: "para buscarle una respuesta a la pregunta de la Pelada” (Millán, 2007: 74-75). El sugerente título del libro - es necesario destacarlo- se refiere al tratamiento homeopático alternativo, a base de veneno de escorpión azul, de una especie endémica de la isla de Cuba (Rhopalurus Junceus) que el poeta decidió consumir para combatir el feroz cáncer al pulmón (enfermedad que también terminara con la vida de Enrique Lihn), y que lo llevó a la muerte, el 14 de octubre de 2006.
} 
paradigmáticos, puesto que es el propio escritor quien va a morir -en los casos de Lihn y Millán-, pero que, escribiendo, logra mirarse desde afuera, en un proceso distanciador o extrañante, que se concreta mediante el devenir tercera persona o el devenir testigo del sujeto de la enunciación, modalidad que Isla Correyero también pondrá en funcionamiento en su propio diario. Cito aquí las palabras de Mendoza que apuntan a la relación intertextual, más bien inacabada, entre los tres autores:

\begin{abstract}
Ahora, escribiendo estas líneas, me asalta Lihn con su Diario de muerte, escrito en la experiencia misma del tortuoso trayecto (falleció de cáncer, escribió su libro en ese trance, que es también tránsito, transformación en tantos sentidos). Pienso también en Veneno de escorpión azul, otra experiencia extrema, del poeta Gonzalo Millán (1946-2006). Enrique Lihn acuñó el concepto de «poesía situada», es decir, la relación directa y comprobable de los enunciados con la circunstancia de su producción. Establezco, entonces, una correspondencia entre el Diario de una enfermera de Isla Correyero y el Diario de muerte de Lihn. [...] Ambas obras comparten el dolor, la enfermedad, la conciencia de la muerte, a través de una escritura coloquialmente conmovedora, a veces lírica, irónica a veces, desplegando un carácter narrativo de una trágica belleza. Ambas escrituras tienen un narrador testigo, un hablante herido sitiado y situado por la enfermedad. En el caso de Lihn, él es el testigo de sí mismo, de su propia destrucción. [...] En Isla Correyero, la testigo asiste al dolor de los demás que, en el fondo, es también su propio dolor. Uno aprendido y aprehendido en la práctica directa: nuestra poeta trabajó más de 20 años como enfermera. (Mendoza, 2014: 26).
\end{abstract}

De este modo, aunque este artículo se focaliza más en el diario de Correyero, es necesario aclarar que la conceptualización de estos textos en tanto escenas situadas en la problemática de la muerte, es válida para los tres autores aquí estudiados, proponiéndose de esta forma, y a partir de la lectura comparada e intertextual, una escena crítica en la que, a través del encuentro entre los textos, se visualiza un diálogo entre los poetas aquí convocados: Isla Correyero, Gonzalo Millán y Enrique Lihn.

\title{
2. Entrada a los textos: hibridación transgenérica e interdisciplinaria
}

La muerte, ese inquietante punctum de la fotografía, que "punza y hiere" según Roland Barthes, ese hápax contradictorio e irrepetible que, según Vladimir Jankélévitch, hace de cada existencia un hecho semelfáctico $(2009)^{7}$, me permite situar

\footnotetext{
7 Vladimir Jankélévitch en su libro La muerte (2009), introduce y aplica diversos conceptos y
} neologismos para definir la condición única, irrepetible e irrevocable de la muerte-propia. El Hápax ("voz 
y describir, entre los textos aquí convocados, diversas escenas o lugares de observación del fenómeno muerte, entendida con Norbert Elias, como "zona biosocial de peligro" (2009: 76). Estas escenas o escenarios verbales se proyectan, desde los textos, en virtud de la hibridación transgenérica del discurso lírico-poético con el discurso autobiográfico y/o memorialístico, que caracteriza la escritura de estos autores. En este cruce de los géneros -el cual permitiría situar una tradición de los diarios poéticos sobre la muerte en la literatura española y latinoamericana contemporánea-, se hace evidente no sólo la fecundidad de los diálogos intertextuales entre la poesía chilena y española ocupada del tema, sino también la búsqueda de una forma literaria -el diario poético en sî́ su vez, logra establecer y casi sin proponérselo, un discurso filosófico, sociológico y antropológico sobre la muerte. De este modo, la escritura literaria pone en funcionamiento ciertas formas de conocimiento de lo real, hibridizándose no sólo en lo que respecta al género, sino también en sus alcances disciplinarios. Así, la escritura literaria es, en estos casos, también filosofía, antropología y sociología de la muerte... Y acaso mucho más.

El escritor, siguiendo a Gilles Deleuze, deviene otra cosa que escritor': es aquí más bien casi un científico de la muerte cuyo campo de estudio es, paradójicamente, su

registrada una sola vez en una lengua, en un autor o en un texto", DRAE) se refiere aquí a la condición de ultimidad que sería la muerte pensada en el "instante mortal"; ese instante, el último, que es "uno solo, y nada más que uno, lo es completamente; ese instante único es el único, en este sentido, en ser último. No hay, por definición, más que un único último instante: pues si hubiera otro después de él, no sería más que el penúltimo... En la medida en que la última vez no es una vez como las demás, debería por tanto enseñarnos algo. Ella es en efecto el Hápax de los hápax; el Hápax por excelencia" (2009: 334). Por su parte, la condición semelfáctica de la existencia se refiere, en Jankélévitch, a la "originalidad de la existencia singular, que es posible o realizable una sola vez". "Semelfactive, del latín, semel, una vez, y factive, posible, realizable" (N. del T.: 24).

${ }^{8}$ Es posible situar en la historia de la poesía chilena casos específicos en los cuales esta hibridación transgenérica e interdisciplinaria se lleva a sus extremos, especialmente cuando los textos tematizan la problemática de la muerte-propia. Casos emblemáticos son aquí los textos: Diario de muerte de Enrique Lihn y Veneno de escorpión azul de Gonzalo Millán; pero también los diferentes poemarios de Armando Uribe Arce, en donde destaca, por su aproximación al diario de vida y al informe de carácter legal, el texto Apocalipsis apócrifo del año 2006. En el mismo sentido, se puede rastrear este fenómeno en la escritura poética de Carmen Berenguer, quien, desde sus primeras publicaciones en poesía, explora la aproximación del género lírico-poético con el diario de vida, tal como se puede leer en su libro Boby Sands desfallece en el muro de 1983, concibiéndose el texto como un registro exhaustivo del tiempo, y como un escenario verbal donde se tematiza la muerte como hecho personal y colectivo, en el contexto de la dictadura militar en Chile. En el caso de la poesía española se observa un marcado anclaje autobiográfico en obras importantísimas de la lírica del siglo XX, a saber: Poeta en Nueva York (1930) de Federico García Lorca, La realidad y el deseo (1964) de Luis Cernuda, ambos autores de la generación del 27'; Diario del artista seriamente enfermo (1974) de Jaime Gil de Biedma; los diversos libros de Eloy Sánchez Rosillo, muy especialmente, Páginas de un diario (1981) y Autorretratos (1989); y la poesía completa de Leopoldo María Panero, entre otros. En estos autores se manifiesta, con mayor o menor grado, una hibridación genérica, entre el discurso poético y autobiográfico, y también una preocupación explícita por el tema de la muerte.

9 "Escribir es un asunto de devenir, siempre inacabado, siempre en curso, y que desborda cualquier materia vivible o vivida. Es un proceso, es decir un paso de Vida que atraviesa lo vivible y lo vivido. La 
propia vida. Devenir, en lo que respecta a los diarios de Lihn y Millán, no significa dejar de ser escritor, pues en estos casos se escribe casi hasta la muerte, sino más bien ser el médico de sí mismo, médico "aun a costa de diagnosticarla (la enfermedad) dentro de sí misma y de luchar contra sí misma” (Deleuze, 1996: 16); médico-escritor que, siendo testigo y protagonista de su propia enfermedad, dirige su atención hacia sí mismo y hacia su propio cuerpo. Pero no sólo ello, el escritor-médico, quien ha reconocido su condición mortal, descubre, ante la inminencia del momento final, la necesidad de alcanzar, es decir, de hacer posible su propia muerte, en el sentido planteado por Maurice Blanchot; y ello implica un devenir mortal: de sujeto mortal (mortalis) a moribundo (moribundus), y de moribundo a sujeto en trance de morir (moriens), para, finalmente, "habitar" en el espacio ulterior del cadáver (mortuus), el cual sólo designaría un estado. La escritura será así el lugar, tanto en Lihn y Millán, donde se ensaya el devenir mortal, el cual, contradictoriamente, no señala ningún devenir más y se establece, de forma tajante, como el límite de todo el ser. Pero frente a estos textos, ¿qué nos dice el diario de la española Isla Correyero?, ¿y cómo dialoga con ellos?

Estamos en presencia, entonces, de textos híbridos y al mismo tiempo interdisciplinarios, puesto que los mismos textos van proponiendo métodos y formas de observación de la realidad, las cuales coinciden aquí con lo planteado por Enrique Lihn y los diversos críticos de su obra, respecto del concepto de "poesía situada"10, y que se aproximan a los métodos de investigación de las ciencias sociales, como la antropología y la sociología ${ }^{11}$. Pero no sólo eso, la presentación formal de estos textos como diarios

escritura es inseparable del devenir; escribiendo, se deviene-mujer, se deviene-animal o vegetal, se deviene-molécula hasta devenir-imperceptible. [...] Devenir no es alcanzar una forma (identificación, imitación, Mimesis), sino encontrar la zona de vecindad, de indiscernibilidad o de indiferenciación tal que ya no quepa distinguirse de una mujer, de un animal o de una molécula". [...] "Escribir es también devenir otra cosa que escritor. A aquellos que le preguntan en qué consiste la escritura, Virginia Woolf responde: ¿Quién habla de escribir? El escritor no, lo que a él le preocupa es otra cosa” (Deleuze, 1996: 11-19).

${ }^{10}$ Señalan Pedro Lastra y Adriana Valdés: "Como se sabe, Enrique Lihn se declaró, desde La pieza oscura, a favor de lo que reconocía como una «poesía situada» y describió esos términos de manera muy precisa como la relación del texto con la circunstancia de sus enunciados. A menudo insistió en esta condición de su escritura, tanto en sus notas como en sus diálogos, pero tal vez ninguno de sus libros corrobore más intensamente ese propósito que Diario de muerte" (Lihn, 1989: 11). En la misma línea, señala Mario Rodríguez: "la relación del texto con las circunstancias de sus enunciados puede ser una buena aproximación teórica a lo que entendía Lihn por poesía situada. La escritura de Diario de muerte reafirma textualmente este procedimiento, proporcionando una suerte de sentido límite a su desarrollo en la poesía de Lihn" (1993: 25).

11 En este sentido, la poesía de Enrique Lihn aparece como indagación interdisciplinaria sobre lo real. Señala Óscar Galindo: "El cuestionamiento de los saberes institucionalizados ha contribuido a este proceso de cambio que caracteriza la condición posmoderna. Lo anterior ha provocado un efecto de inestabilidad e hibridaje de los saberes y disciplinas, de los métodos de conocimiento de la realidad social y de los mecanismos de representación de la «realidad», así como de la construcción autorial, 
poéticos de vida y muerte -uno de cuyos rasgos sería, por ejemplo, el detallado registro del tiempo en los diarios de Millán y Correyero-, se complejiza aún más al observar que, en vista del devenir transgenérico de los textos, estos aceptan otras formas discursivas: secuencias narrativas, dramáticas y ensayísticas, hasta más específicas, como cartas, confesiones, informes, notas y todas aquellas formas marginales que, con mayor o menor grado en cada autor, determinan la presentación final del texto como libro $^{12}$.

En este contexto, "la salud como literatura, como escritura, consiste en inventar un pueblo que falta". El objetivo último de la literatura sería, según Deleuze: "poner de manifiesto en el delirio esta creación de una salud, o esta invención de un pueblo, es decir una posibilidad de vida. Escribir por ese pueblo que falta («por» significa menos «en lugar de» que «con la intención de»)" (1996: 15-16) ${ }^{13}$. Pero ¿cuál sería ese pueblo inventado en límite del ser y proyectado, desde la escritura, en ese lugar que más bien sería un no-lugar, y donde más bien el ser se hundiría en el no-ser del vacío y la nada? Es necesario enfatizar, siguiendo a Maurice Blanchot que, en lo que respecta a las escrituras de Lihn y Millán (pero también de Correyero, como se verá), la búsqueda

modificando de manera radical el discurso poético tradicional" (2002: 226). Es ese "discurso poético tradicional" el que Lihn cuestiona, debido a su inestabilidad, a partir de textos como La pieza oscura (1963) y la serie de Poesía de paso (1966), hecho que culminará en la publicación póstuma del diario, el cual, según Mario Rodríguez, "puede leerse como una epifanía de toda la escritura del poeta Enrique Lihn” (1993: 25). Este estallido posee diversas líneas donde se actualiza el devenir de los textos: su mutación hacia lo distinto, su peculiar forma de apartarse incluso de lo poético o de lo lírico en sentido tradicional, para transformase en registro antropológico, en nota o acotación. Esta especial característica interdisciplinaria es destacada por Galindo a propósito de la intertextualidad refleja apuntada por Pedro Lastra en las famosas conversaciones con el poeta. Escribe Galindo: "Es seguramente esta obsesión la que lo lleva a explorar en procedimientos y técnicas que podrían considerarse propios de las ciencias sociales. Así, la llamada «escritura situada» le hace aparecer muchas veces como una suerte de irónico etnógrafo cuando se enfrenta a culturas ajenas o de investigador social cuando transita por la propia, recurriendo a procedimientos de escritura propios del libro de viaje, del testimonio o del registro etnográfico. Nos enfrentamos así [...] a una poesía antropológica y cultural, articulada a partir de tensiones y mutaciones discursivas que complejizan la definición del texto poético.” (2002: 228).

${ }^{12}$ La aparición de estos textos -que transitan entre lo lírico-poético y el diario de vida- respondería, en el contexto de la literatura hispanoamericana de la segunda mitad del siglo XX, a los diferentes fenómenos de hibridación cultural descritos por Néstor García Canclini, en su ensayo Culturas híbridas: estrategias para entrar y salir de la modernidad (2001). La hibridación textual apunta aquí, como se ha dicho, a lo transgenérico y a lo interdisciplinario de estas escrituras.

${ }^{13}$ A su vez, los tres textos en cuestión actualizan lo señalado por Gilles Deleuze al comienzo de su libro Crítica y clínica (1996), a propósito de la condición del escritor: "El escritor como tal no está enfermo, sino más bien es el médico, médico de sí mismo y del mundo. El mundo es el conjunto de síntomas con los que la enfermedad se confunde con el hombre. La literatura se presenta entonces como una iniciativa de salud: no forzosamente el escritor cuenta con una salud de hierro [...], pero goza de una irresistible salud pequeñita producto de lo que ha visto y oído de las cosas demasiado grandes para él, demasiado fuertes para él, irrespirables, cuya sucesión le agota, y que le otorgan no obstante unos devenires que una salud de hierro y dominante harían imposibles. De lo que ha visto y oído el escritor regresa con los ojos llorosos y los tímpanos perforados (1996: 14-15). 
infatigable consiste en "establecer con la muerte una relación de libertad" (2006: 181). Morir libremente o morir contento; palabras que encierran en Kafka una "exigencia circular": "Escribir para morir, Morir para escribir" (2006: 179). En suma, he aquí la búsqueda, la dirección del arte según Blanchot, la cual se relaciona con la intención de fundar ese pueblo, siempre inacabado y en constante devenir (Deleuze), incluso cuando el escritor sabe que ese pueblo sólo será posible en la medida en que es utópico: un pueblo situado en otro mundo, el cual paradójicamente no es otro y ni siquiera es un mundo ${ }^{14}$.

Ahora bien, ¿qué "supremo dominio" se yergue, entonces, en los textos de Lihn, Millán y Correyero? ¿De qué manera estos poetas establecen con la muerte una relación de soberanía? ¿Cuál es, en definitiva, el poder, y por lo tanto el saber, de estos escritores situados, de modo obsesivo, en el escenario de la muerte? Y de modo particular, y frente a los diarios de Lihn y Millán, ¿cuál sería el poder, y por lo tanto el saber, de una escritora (Correyero) quien, devenida enfermera, relata su propia visión acerca de lo que implica ver morir y acaso morir con el otro?

\section{Acto único: Diario de una enfermera de Isla Correyero ${ }^{15}$}

a. Escena I: Enfermos, moribundos

El espacio presentado en el texto de Isla Correyero corresponde al "espacio fantasma" (Correyero, 1996: 13) de la clínica; "espacio fantasma" puesto que se trata de un lugar de tránsito y de "intercambio simbólico" con la "alteridad radical" (Baudrillard); "espacio fantasma" porque también será el lugar del paso que, en el imaginario poético de la autora, hace posible incluso el utópico retorno de los espectros.

\footnotetext{
${ }^{14}$ Frente a ello, la literatura, la poesía, se establece como búsqueda de una soberanía y un deseo de poder que insiste en decir lo indecible e inefable de ese lugar llamado muerte, en cuya proximidad se afina "el arte de decir el mundo". Señala Blanchot, respecto de Kafka: "Sólo se puede escribir si se permanece dueño de sí mismo ante la muerte, si con ella se han establecido relaciones de soberanía [...] Kafka siente aquí en lo profundo que el arte es relación con la muerte. ¿Por qué la muerte? Porque es el extremo. Quien dispone de ella, dispone en extremo de sí, está vinculado a todo lo que puede, es íntegramente poder. El arte es dominio del momento supremo, supremo dominio." (2006: 173).

${ }^{15}$ La visualización de escenas (o "unidades escénicas") del texto poético responde a una operación de corte y descomposición de la totalidad del texto, para describir, desde la unidad establecida, la totalidad significativa de la obra, tal como se desprende del análisis aplicado rigurosamente por Marta Contreras en su estudio sobre la obra dramática de Griselda Gambaro (1994). En este sentido, se trata de dividir y esquematizar la totalidad del universo textual, bajo conceptualizaciones funcionales que permitan justamente recorrer, visualizar y experimentar la totalidad del espacio poético creado por el autor. Si bien, la operación de corte es arbitraria y responde a una necesidad crítica de visualización de la totalidad del texto, cada escena (o "unidad escénica") debería proyectar, en teoría, una lectura en profundidad de todo lo visto y oído en el conjunto de textos. La conceptualización de estas escenas ("unidades escénicas" y/o poéticas) constituyen, en definitiva, una metodología de lectura que aquí se intenta actualizar y revalidar.
} 
La clínica será así lugar donde nuestra enfermera observa la brutal acción de la muerte en el mundo; observa la "alta potencia de la muerte" (Blanchot), la cual hace inclinar la cabeza y obliga a cuestionar todo lo humano: "Inclino la cabeza para que nadie sepa que ya no soy humana. / Debemos pasar inadvertidos. / Todos los enfermeros provenimos de una raza de autómatas". Y luego: "Yo no conozco a nadie que pueda ser humano / ¡Hay tanta muerte y tanto olor a muerte!” (1996: 11).

Sin embargo, la enfermera no abandona su labor de autómata, más aún, descubre que asistir a los enfermos y a los moribundos, también implica verse morir con ellos: verse morir en los plateados ojos de los muertos. Con ello, el sujeto del texto descubre una forma de relación filial con sus enfermos y sus muertos. El amor y la muerte se dan cita en el quirófano: "Pasan cosas terribles y sagradas en los bosques del quirófano. / Ayer pasó la muerte y el amor por ahí y nos llenó de sangre y nos llenó de rosas. / En esa mesa fría de acero inoxidable cayó la imperfección de la niña operada” (1996: 17). En este aspecto, el poema se constituye como una auténtica visión ${ }^{16}$, es decir, una mirada en profundidad que destaca por su lucidez casi científica, aquí coincidente, como se ha dicho, con una concepción situada de la escritura, pues a través de esa mirada se proyecta un escenario -en este caso, el quirófano- y una escena, con sus respectivos sujetos y/o personajes, cargada de un dramatismo trágico, el cual sólo será soportable a través de la distanciación que se activa mediante el artificio de la escritura.

El sujeto testigo es tal, en cuanto sus visiones se presentan como una indagación situada en un escenario concreto -la clínica-, pero más allá de eso, también se trata de una visión detenida, muy particularmente, en la acción de la enfermedad y de la muerte en el cuerpo, pues ahí es donde sucede el hecho empírico y biológico de la muerte, aun cuando la muerte sea al mismo tiempo un misterio de "dimensiones metaempíricas": "He visto el dibujo de la enfermedad y el ramo verde de su rigurosa manifestación, pero no sé en quién está encerrada" (1996: 12). Nótese, en este aspecto, que el poema deviene sobre todo pregunta: indagación casi filosófica -por el ser de la muerte o por la muerte en sí-, la cual se ancla en la visión perturbadora del cuerpo enfermo y de su

\footnotetext{
${ }^{16}$ Gilles Deleuze, en Crítica y clínica (1996) sostiene, entre otras cosas, que escribir es tener visiones; visiones que al mismo tiempo son audiciones, que pasan intensamente por el cuerpo sensible del poeta. La lengua extranjera, en la cual se enuncia toda verdadera literatura, está construida, según Deleuze, de "un envés consistente de Visiones y Audiciones que ya no pertenecen a ninguna lengua. Estas visiones no son fantasías, sino auténticas Ideas que el escritor ve y oye en los intersticios del lenguaje, en las desviaciones del lenguaje. [...] El escritor como vidente y oyente, meta de la literatura: el paso de la vida al lenguaje es lo que constituye las Ideas (12).
} 
"destino humano"17: “¿De dónde viene el débil silencio que aparece rodeando la dulce anatomía de un destino humano?” (1996: 12) ¿De dónde, en suma, viene la muerte?: “¿De qué impasible órgano imperfecto nos llega la primera noticia de la muerte? ¿ ¿A quién le tocará la sombra fría de esa interrogación que crece y crece? (1996: 12). Así, frente a la acción de la muerte en el mundo, sólo queda la pregunta ante el Hápax incomprensible. Pero la muerte sigue siendo al mismo tiempo misterio ${ }^{18}$, y la poesía no deja de forcejear con el misterio, se yergue como discurso de poder (y saber) y como búsqueda de una total lucidez ante la inminencia del momento final: "Aquí la lúcida facultad del amor y la muerte se acoplan en el mismo espacio turbulento" (1996: 18).

La voz es testigo, es la voz de una "cansada enfermera" (1996: 19), quien, sin embargo, no puede dejar de mirar, pues dentro de los intramuros de la clínica todo escamoteo de la muerte es inútil y absurdo. Pero la clínica es también el lugar de encuentro con la inconcebible belleza del momento final. El sujeto del texto -nuestra lúcida enfermera-, observa la belleza, estudia la belleza, sin piedad, como se declara enfáticamente en el poema "Muerte de un niño": "Es misterioso ver morir a un niño enfermo. / (La piedad no existe para quien observa la belleza). / Su corazón continúa deslumbrando la cama. Durante el dulce ejercicio del pecho desnudo, la boca contiene una profunda sombra que alienta todavía." Y más tarde el sujeto testigo, también quedará casi inmovilizado ante la visión, pero sólo casi, pues la visión es también conocimiento y revelación: "El polvo de la muerte te ha cambiado los ojos y caes, sin movimiento, al último latido. / (La piedad no existe para quien estudia la belleza)" (1996: 25).

De este modo, la clínica del poeta será un escenario de investigación casi científica de la muerte: se trata de saber qué es la muerte en sí, pero también y de un modo mucho más personal aquí, se trata de saber, desde la perspectiva de nuestra enfermera, qué es un muerto: ¿un “azul cadáver” o un “cadáver muscular”? Empero, en

\footnotetext{
${ }^{17}$ Desde un punto de vista antropológico se puede señalar, con Nigel Barley, que "las ideas relativas a los que significa estar muerto forman parte de una idea más general de lo que significa ser un ser humano vivo, y que el comportamiento funerario y las creencias existentes en todo el mundo son interpretables como un prolongado diálogo acerca de la noción de persona" (2005: 35). ¿Qué sucede, en definitiva, con la persona que muere o cuál es su "destino humano"? Esta pregunta, sobre la "mismidad" de la persona que muere, es también la pregunta que se enuncia en los diarios de Correyero, Millán y Lihn, convirtiendo a estos textos en registros antropológicos sobre la experiencia del morir.

${ }^{18}$ Para Vladimir Jankélévitch la muerte "por una parte es un misterio de dimensiones metaempíricas, es decir, infinitas, o mejor aún sin dimensiones de ninguna clase, y por otra parte es un acontecimiento familiar, un hecho de la empiria que tiene lugar en ocasiones ante nuestros ojos" [...] "La muerte es en primer lugar una evidencia de hecho, una evidencia obvia y familiar. Y sin embargo esta evidencia, cada vez que nos la encontramos, ¡nos parece siempre tan chocante!” (2009: 18-19).
} 
el espacio de la clínica, la vida quiere continuar a pesar del No rotundo de la muerte, pero se trata de un deseo precario, propio de cuerpos más bien frágiles, lo mismo que el heroísmo de nuestra enfermera, el cual es frágil, y por ello mismo más humano. No se trata aquí de vencer a la muerte, sino de establecer con la muerte otro tipo de relación. En ello, el poema no sólo presenta el espacio de la clínica como aquella "zona biosocial de peligro", sino que también es denuncia sobre la condición del morir en nuestras sociedades contemporáneas ${ }^{19}$.

Paradójicamente, siendo la clínica un lugar de muerte, algo lucha por vivir: un embrión o un enfermo terminal, por ejemplo. Pero la potencia de la muerte se manifiesta con toda su crudeza, en el texto de Correyero, y sólo es posible mirarla de frente "con un lenguaje limpio". El sujeto explora, observa la precaria resistencia de ese embrión que (se) muere envuelto en heces: "Sigilosamente, alguien desconecta la máquina y la luz. / Ha muerto dulcemente envuelto en unas heces más negras que la tinta. / Su madre le ha traído un pañal y un trajecito de hombre” (1996: 30).

\footnotetext{
${ }^{19}$ Los tres textos aquí reunidos son auténticos testimonios sobre la experiencia del morir, ya sea desde el punto de vista del enfermo terminal (Millán y Lihn), o desde la mirada-testigo de la enfermera (Correyero). En los tres textos se percibe una intención crítica, social y cultural, que logra establecer, casi sin proponérselo, una diagnosis en profundidad sobre la experiencia del morir. En este aspecto, quizás el problema más punzante de nuestra manera de experimentar el hecho de la muerte sea, siguiendo a Norbert Elias, el vergonzoso problema del abandono de los seniles y moribundos, en suma, la soledad de los moribundos. Señala el autor: "El quebrantamiento de la salud suele separar ya a los que envejecen del resto de los mortales. Su decadencia los aísla. Quizás se hagan menos sociables, quizás se debiliten sus sentimientos, sin que por ello se extinga su necesidad de los demás. Eso es lo más duro: el tácito aislamiento de los seniles y moribundos de la comunidad de los vivos, el enfriamiento paulatino de sus relaciones con personas que contaban con su afecto, la separación de los demás en general, que eran quienes les proporcionaban sentido y sensación de seguridad [...] El hecho de que, sin que se haga de manera deliberada, sea tan frecuente el aislamiento precoz de los moribundos precisamente en las sociedades desarrolladas, constituye uno de los puntos débiles de estas sociedades. Atestigua las dificultades que encuentran muchas personas para identificarse con los viejos y los moribundos" (2009: 20-21). En consecuencia, la muerte se niega y se esconde: "La muerte en cuanto proceso y pensamiento, se va escondiendo cada vez más, con el empuje civilizador, detrás de las bambalinas de la vida social. Para los propios moribundos, esto significa que también a ellos se les esconde cada vez más detrás de las bambalinas, es decir que se les aísla" (2009: 33-34). En respuesta a ello, el autor señala: "En la actualidad, las personas allegadas o vinculadas con los moribundos se ven muchas veces imposibilitadas de ofrecerles apoyo y consuelo mostrándoles su ternura y afecto. Les resulta difícil cogerles las manos o acariciarlos a fin de hacerles sentir una sensación de cobijo y de que siguen pertenecientes al mundo de los vivos. El excesivo tabú que la civilización impone a la expresión de sentimientos espontáneos les ata muchas veces manos y lenguas" (2009: 56). Habría, en suma, una antipatía hacia los moribundos: "una antipatía que suele ser tácita pero no por ello menos perceptible, de los vivos hacia los que están muriendo, una antipatía que muchos miembros de estas sociedades no son capaces de superar aun cuando no la aprueben. El hecho de morir, se mire como se mire, es un acto de violencia" (2009: 136). Sin embargo, la enfermera Isla Correyero, aun reconociendo y resistiendo la violencia de la muerte, responde de modo diametralmente opuesto a esta actitud generalizada, de negación, frente a los moribundos y los muertos: ella no solo los atiende, sino que los acepta y acoge; y de ello da cuenta el registro de su diario.
} 
Ver la belleza en los moribundos. Ver la belleza del instante mortal. Ver la belleza en la muerte. La visión continuada de la enfermera es también una forma de castigo, de cadena perpetua: el juego de las miradas ata, encarcela o aprisiona tanto al sujeto enfermo como a la propia enfermera. "Cadena perpetua": "Oh dulce criatura de 17 años! / ¡Oh dulce enfermo hueco de 37 kilos!, que ya estás bordeando la madura belleza de la muerte". Y, sin embargo, hay que verlo e incluso decirle: "Verte tan triste como la mariposa azul que vigila tus ojos es para los que te cuidamos un dolorido y materno viaje hacia los bosques”. Y más aún, ver -acción que aquí corresponde a mirar en profundidad-, implica querer mirar a través de los ojos del quien va a morir: “¿Qué ves tras los cristales turbios de la ventana? / ¿Qué cárcel es esta pequeña habitación a donde sólo llega el soplo cansado de tu oxígeno!” (1996: 31).

En este traspaso de la mirada, del sujeto-testigo al sujeto-enfermo, se cifra el salto ético de esta poesía: no es el sufrimiento de la enfermera el que se expone como centro de la situación dramática, sino precisamente el dolor del otro, del cual resulta el conocimiento de la ultimidad de la propia muerte. Pero para ello será necesario un salto hacia el otro, lo cual también implica un grado de identificación con aquél que va a morir. En este sentido, un pequeño gesto evidencia el gran salto de la perspectiva del yo al otro: la enfermera que ve morir, no usa el "se muere", usa el "me muere", pero para ello es necesario de algún modo "entrar en la muerte" del otro, y ello se logra agudizando la sensibilidad poética ante la dramática potencia del momento final. Dice el sujeto: "Me han elegido para entrar en la muerte de una niña" (1996: 35), y luego: "Agua y amor me pide la que muere. / De una bolsa de suero glucosado le doy a la privada criatura un sorbo, / un sorbo lento. / Traga, / traga, / mi amor, / mi amor, / mientras me acuesto a su lado / besándonos, me muere" (1996: 36).

\section{b. Escena II: “Terminales" / Espectros: "Muertos, sombras"}

La muerte del otro es así casi exactamente la propia muerte, pero sólo casi, y para mirarla de frente es necesario aprender a mirar los distintos aspectos de la enfermedad y ello implica atender cuerpos que se debaten entre la vida y la muerte. "Los terminales": "Son seres desafortunados. / No luchan ni leen. / Saben que ya están muertos" (1996: 39); y, sin embargo, ahí están, los enfermos terminales, con las "cosas del desaliento", "de la amargura", “del abandono", "de la fisiología y de la pobreza”, frente a lo cual la enfermera se preguntará, extrañada: “¿Para qué quiere un cepillo de dientes un moribundo?" (1996: 42). El texto es un estudio poético de la muerte y sobre la 
condición del moribundo. El sujeto-testigo está destinado ahí para situar, con su mirada, sólo escenas dentro del gran escenario de la clínica.

El "celo fronterizo" que separa a los vivos de los muertos y del cual hace "gala el mundo", va separando también a los enfermos terminales, como bien lo sabe el sujeto de los poemas "Día de los muertos” y "Hay sólo dos países” de Enrique Lihn (1989: 27, 57-58). Y de alguien debe ser la culpa de tanto abandono, soledad, dolor y muerte. La culpa, ¿de quién es la culpa?, ¿de los vivos o los muertos? Escribe Isla Correyero: "Nosotros no somos culpables, el dolor y la muerte es de ellos mismos. / Hoy, hemos notado que nos miran como adversarios. / Pero no es así. Nosotros no somos culpables", "Pero nosotros no somos culpables de nada. / De nada" (1996: 46). El amor, "poderoso como la muerte" parece ser, sin embargo, más débil que la enfermedad. Pero en la enfermedad, paradójicamente, se afina el amor. El sujeto casi no habla, es testigo, es pura mirada, como se lee en el poema "Lucidez": "Lo que he visto", dice el sujeto, esto es, he visto morir: "Comprendo sin deformaciones lo que he visto. / Ha entrado en mí la exacta conciencia de la muerte. / Me he tomado el tiempo necesario para respirar y he descendido a un paisaje desconocido para el corazón”. El poema es una auténtica visión. El cuerpo del moribundo contiene el universo: "En la garganta de la moribunda se abrían las montañas. En sus ojos abiertos chocaban las estrellas" (1996: 49). La enfermera busca frenéticamente detener el tiempo de la muerte, detener la ejecución de la muerte, frenar su velocidad. Mirar, en este aspecto, implica detenerse a mirar e ir lento, implica la posibilidad de una pausa, como en el diario de Millán, pero, sin embargo, declara la enfermera: "Yo no sé qué lentitud he de ponerle a mis palabras para resistir el olor de la ictericia”, porque “¡Es tan lento morir sobre las telas blancas! / Qué poca cosa nacer y resistirse para morir a un precio tan azul”. Pero mediante la pausa el sujeto accede plenamente a la visión. Hay que detenerse dos veces. Es el efecto de extrañamiento que provoca la escritura poética situada en la visión de la muerte: “Ahora lo escribo sin deformaciones (o con la deformidad de su propia esencia) y percibo que ha entrado en mí, sin la dulzura, la imborrable conciencia de la muerte" (1996: 50).

Poesía, en suma, con valor conocimiento. El diario de la enfermera deviene estudio de campo in situ de la muerte. Una enfermera que escribe poemas le presta sus ojos a la ciencia del entendimiento de la muerte, esa "ciencia nesciente" según Jankélévitch. El poema deviene informe antropológico, estudio en terreno de la mortalidad, tesis sobre la lucidez de la mirada poética detenida ante el momento final. El sujeto se mantiene situado ante la visión de todos los cadáveres, de todos los 
muertos. Sera necesario situarse, de esta manera, en la posición de los moribundos, a media luz o apenas iluminado por la luz de la melancolía: "Vengo con las heridas de los avasallados", dice el sujeto. La voz, de este modo, se transfiere al enfermo terminal, quien no hablaba, y así la muerte del otro se experimenta casi como la propia muerte, como sucede en el poema "Terminal", donde la enfermera deviene sujeto moribundo: "Sé que voy a morir antes del próximo invierno", "He plantado las flores de mi tumba" y, sin embargo, no del todo se abandona la labor de la enfermera: "Creo que cuando lleguen los azules momentos del invierno, estaré todavía trabajando" (1996: 54-55).

A través del poema el sujeto asciende "al soñador hallazgo de una ardiente tragedia": cuidar hasta el último momento a los que van a desaparecer, y así el dolor se purga a través de una catarsis plena, pero sabiendo al mismo tiempo que todo lazo, como la vida misma, es frágil. La enfermera va creando así una voz, mientras va afinando su visión. Con los moribundos que hablan de su pueblo, la enfermera que escribe, "adora descifrar, el asombroso acento lento de nuestra lengua" (1996: 56-57), pero mirando de frente el color azul de la muerte y de los moribundos. En este aspecto, los poemas dedicados al padre constituyen un claro ejemplo de lo que implica devenir en el otro en trance de morir, esto es, alcanzar el grado de indiscernibilidad tal que ya no quepa distinguirse de él. De este modo, el padre moribundo le habla a su hija enfermera, pero es ella quien copia y transcribe el mensaje: "No tengo tiempo para ponerme a iluminar tu corazón. / Veo que la vida se me escapa como algo vacío y negro.” Y luego: "No me arranques respuestas ni te pierdas conmigo. / Sigue mirándome los grandes azules de mi enfermedad" (1996: 60). E inmediatamente, en la siguiente página-escena, el sujeto del texto observa la "impasible", "dura" y triste labor de las limpiadoras, para quienes "Los enfermos son otra basura en movimiento". Frente a las limpiadoras, las cuales "han marcado la habitación con el olor boreal de la lejía", el padre enfermo domina, "paciente y distinguido" y ella, la hija, "le limpia el corazón" con su "uniforme de enfermera" (1996: 61). En todos los sentidos, es menester limpiar el escenario de la muerte. De esta manera el poema, como conjunto, es una diagnosis sobre cómo se muere, un diagnóstico in situ sobre la condición del morir. Hay en estos poemas, una socioantropología de la muerte, y no solamente una filosofía o anti-filosofía de la muerte.

Así, la enfermera descubre que "La enfermedad une más que el amor”. ¿Será porque la muerte expande los límites del amor o será porque la enfermedad, como 
último tiempo del moribundo, es el último tiempo disponible para amar? La enfermedad une así más que el amor y quizás más allá de la muerte. Los moribundos buscan abrazarse, se desnudan en los pasillos buscando abrazar otro cuerpo: "Aquí, los paseantes pálidos, / van atravesando sus pérdidas y se arriman, / unos a otros, / como huérfanos despedazados por la luna" (1996: 62). La enfermera es una heroína frágil, frágil porque sus ojos se enferman con el color azul de la muerte. Aun así, ella sabe algo, un "pequeño conocimiento", el cual le otorga esa "pequeña salud" definitoria de la condición del escritor, según Gilles Deleuze. La enfermera, heroína frágil, es asediada por la muerte, pero en su trabajo contra ella también descubre el amor. La relación con el enfermo es personal: "mi enfermo", dice. Cuando la muerte ataca con sus “¡Oh pájaros del miedo! ¡Oh, violencias azules!”, el sujeto claramente muere con el otro: "He perdido mi vida, yo también. / El relámpago agita los ojos de mi muerto" (1996: 65).

Y, sin embargo, algo se mueve. "Pero se mueve", dice el sujeto. El muerto es aún alguien profundamente vivo, para el hablante de esta poesía: "se mueve para mí, se mueve con los pájaros que vienen del ensueño", "Su lecho dolorido me dice que él existe", "Él existe y se mueve", "Ha vuelto para mí. / Toco su pecho. / Me veis: Hablo de él como si nada hubiera sucedido. / ¡Oh médicos malditos!” (1996: 66-67). La muerte del otro es casi la propia muerte. Todos los sujetos que sobreviven al fallecimiento también experimentan una forma de morir, en tanto viven el luto y el duelo.

El poema deviene elegía sobre la muerte del padre, pero antes de ello el deceso ha de ser un hecho más de la empiria, una fecha y una hora en el registro de defunciones, pero que arrastra a todos los sujetos del duelo, especialmente a la hijaenfermera, a un devenir en extremo mortal: "Mi padre ha muerto el día 13 junio a las 13 horas y 13 minutos de este 1995 azul. / Ha cambiado el mundo, el añil de las cosas / Todos hemos pasado al frío vertiginoso de los abandonados" (1996: 68); pues es totalmente cierto que el mundo sin él ya no será el mismo, en tanto el hecho semelfáctico de la existencia del padre es, de suyo, irrepetible. Frente a la muerte del padre, sólo es posible estar ahí; "De cuerpo presente": "Sólo por ti / que acaso todavía estás de cuerpo dulce, / intocado, ligero, más profundo que el mar. / Sólo por ti, padre, conmigo, / Soy capaz de escribirte a esa isla remota / en la que rompen las olas todo mi corazón". Y luego: "Y estás azul, mirándome". Los vivos son así la gran sepultura de los muertos: Antígona de Sófocles, María Zambrano, Griselda Gambaro, pero también 
Isla Correyero: “¡Dime tú, ilimitado, qué hacer para enterrarte en mi cuerpo de sombra!” (1996: 69)... ¡La respuesta es escribir!

El diario deviene así metapoesía, arte poética: "Para quién escribo", poema que dialoga con "Porque escribí" de Lihn, en tanto escribir "significa trabajar con la muerte / codo a codo, robarle unos cuantos secretos", "Pero escribí y me muero por mi cuenta, / Porque escribí, porque escribí estoy vivo" (Lihn, 1996: 176). Se escribe, pues, desde la perspectiva de la enfermera, para quienes van a morir, para los vivos. Entonces el texto se convierte en una dilatada enumeración de sus destinatarios: "para todos los que sufren en esta larga galería de la muerte. / Para los que lloran por el clima y desfallecidamente caen entre las sábanas mojadas. / Para las madres que nunca acaban de perder al hijo", "para los ancianos", "para las alas fosfóricas de la guadaña", "para los hijos", "para las hermanas levísimas", para "el dulce niño" que aún no comprenderá estas palabras, "para los enfermos atados a las camas", "para las esposas continuas", "Escribo, Paolo ${ }^{20}$, para el amante que no podrá entrar a besar a su amado", "para valorar el trabajo de las limpiadoras", "para los delicados y sorprendentes celadores"; y muy especialmente: "Para las enfermeras azules de la eternidad y sus ayudantes, los médicos humildes". La escritura es entonces un escenario clínico donde todo devenir constituye un "devenir mortal”, como lo explica Gilles Deleuze en Crítica y clínica. Se escribe por los animales enfermos, por los cuerpos de los moribundos: "Querido niño azul, yo escribo para los animales que trabajan en el ovillo de la hierba y nunca acaban de vagar por el animalario". Y sobre todo se escribe para él, el padre muerto, y de este modo la escritura es más bien la expresión de un duelo inconcluso, más bien eterno: “yo escribo para él, tú ya lo sabes, para él que se ha ido en esta primavera y se ha llevado todo mi derrumbado diccionario de medicina" (1996: 70-72).

La escritura deviene rito, es decir, expresión del duelo, como sucede en el poema "Madre viuda". Pero más aún, la escena revierte el carácter fatal del apocalipsis, del fin del mundo: "Empapada de sal y de sangre entré misteriosamente en el hospital y percibí toda la muerte". Así los muertos retornan: "Mi padre ha vuelto desde la raya roja del crepúsculo y lo he amado hasta pordiosear sus lágrimas. / He salido del tiempo: ya conozco la soledad del pasado y del futuro". Y luego, hasta la inconcebible conclusión:

\footnotetext{
${ }^{20}$ Se refiere aquí a su hijo, Paolo Álvarez Correyero, también poeta. En este aspecto, el diario poético se aproxima, muy sutilmente, al género epistolar.
} 
"Entre mis compañeros de trabajo hay una fría complicidad para matar. / Unas borrosas señales han aparecido en las paredes. / Todos, todos estamos muertos” (1996: 75).

Pero más aún, los muertos son sombras que se vislumbran en el cuerpo sufriente del observador, como se prefigura en el poema "El moribundo". Morir es perderlo todo hasta la propia sombra, figuración del alma: "Y tengo miedo de eso, / de ese pequeño gesto natural de mojar la cama / y que no importe a nadie, ahora, / porque tengo ya la atribución de exponer todas mis pérdidas, incluso la de abandonar la sombra que proyectan mis párpados azules esta noche" (1996: 80). De este modo, se llega inevitablemente hasta la figuración del cadáver y del espectro que (nos) mira, tal como se lee en el poema "El mortuorio". El espectro se hace presencia: "Es perceptible el espectro del cadáver sentado en el raso del ataúd mirando a todos". El espectro de ese padre muerto retorna y mira, pero no dice nada, a diferencia de la sombra del rey Hamlet: "da pasos hacia ella pero no llega nunca". Los trabajadores de la muerte realizan sus tareas. El celador, "con un gesto de lúcida rutina ha resuelto la muerte". Hay que cerrar el ataúd y sacar al muerto. Pero el espectro está ahí, mira la escena: "Nadie duda que el espectro que vieron fue un fenómeno ajeno a toda lógica" (1996: 81-82).

Hay que mirar hasta el final a los muertos, nos dice el sujeto de esta poesía, ya en el límite de todo lo decible sobre la condición de los muertos. Es así como el sujeto descubre lo siguiente: "Nada pasa en la muerte que no esté deslumbrado", es decir, visto y oído. La visión se traspasa al lector. Él, como el sujeto, también habrá de ser un muerto: "-No importa que me crean. Yo sólo digo esto que / pasará a las manos de un muerto, como yo, / con las manos abiertas que contemplo este libro-." (1996: 83-84). Para entrar en la muerte, será necesario ver el cuerpo muerto, de frente, en una auténtica lección de anatomía fantástica. El poema "Anatomía patológica" es esclarecedor en sus visiones y transgresiones: "Y destapé a la muerta creyendo que era un bulto sin más, / un bulto blanco tapado con la sábana. / Pero estaba la cínica rizada de gusanos / y enrollada en la sangre de sus caderas duras". La enfermera descubre que para entrar en la muerte es necesario unirse inseparablemente, fuertemente a su muerta, "aquella rubia desnuda y amarilla", "aquella falsa", "la más fiera asesina que nadie viera nunca": "Quise gritar y, entonces, como un limón de sangre / me exprimió / cuerpo a cuerpo con ella y sus espíritus." [...] "Toda la noche estuve muriéndome en la bestia, / hablándole 
de tantos secretos de mi infancia. / Y ella, enemiga y viva, tomó mi esencia y forma / y hoy anda por los bares bebiendo con los hombres" (1996: 86-87)

\section{Desenlace, a modo de conclusiones}

Para proponer un desenlace al recorrido escénico propuesto a propósito del conmovedor Diario de una enfermera de Isla Correyero, me parece oportuno retomar algunas consideraciones críticas en torno al concepto, fundamental en esta propuesta crítica, de una "poesía situada". Al respecto, Mauricio Ostria, en su artículo "El espejo roto. Notas sobre la poética de Enrique Lihn" (2005), ha explicado cómo, lo que aquí se ha entendido como un devenir transgenérico entre la poesía y el género autorreferencial del diario de vida, es el resultado de la disolución misma de los géneros, todo ello en el contexto de las múltiples experimentaciones discursivas practicadas por Lihn en su "poesía situada":

La distorsión que experimentan los paradigmas centrales en las "inmediaciones americanas" se evidencia, por ejemplo, en la tendencia a la disolución de los géneros. Formas como la épica lírica, la poesía conversacional, la antipoesía, la poesía ensayo, la novela lírica, la antinovela, la novela ensayo, el cuento novela, las formas paródicas, los textos translingüísticos o las formas de irrupción de la oralidad en la escritura tienden a romper las barreras, a borrar los límites precisos entre diferentes tipos discursivos (2005: 112).

Ahora bien -es necesario destacarlo-, los diversos procedimientos de hibridación transgenérica habían sido practicados por Enrique Lihn desde sus primeros libros, muy especialmente, desde La pieza oscura (1963), donde, como advierte Ostria en un artículo anterior: "el texto lírico se expande para admitir en su interior estructuras narrativas y dramáticas" (1992: 50); lo cual singulariza especialmente el concepto de "poesía situada". Así, "la escritura de Lihn se torna proteiforme y extremadamente intertextual y, al mismo tiempo, fuertemente ligada a la circunstancia histórica: poesía 'situada"” (1992: 51). En consecuencia, la "poesía situada" permite la entrada de los llamados "géneros pragmáticos (narrativo, dramático, ensayístico)", es decir, de aquellos que "suponen una mayor vinculación contextual que la poesía" (1992: 52).

\footnotetext{
${ }^{21}$ El poema "La fauna de los cadáveres" es aún más explícito en sus transgresiones en torno a la visión del cadáver. El poema es claramente una visión sobre el proceso de descomposición, pero en ello se sugiere una intención ritual. Los últimos poemas del Diario de Correyero (en especial "Cerezo", "La fauna de los cadáveres" y "Ana la azul”) parecen activar la función ritual de escritura poética, presentándose como escenarios simbólicos para experimentar la vivencia del luto y del duelo.
} 
Pues bien, dicha mayor vinculación contextual alcanza su mayor grado cuando el texto poético -el libro de poemas, concebido desde su raíz como texto poético- ${ }^{-}$, decidida y descaradamente, se transforma, de forma parcial o total, en diario de vida y muerte, es decir, en discurso autobiográfico; pero lo anterior -en los casos de Lihn, Millán y Correyero-, no supone necesariamente una irrupción desbordada de la subjetividad, sino todo lo contrario; o, al menos, no solamente aquello.

La "poesía situada”, especialmente entendida aquí como una poesía escénica y visual, contextualizada irreductiblemente en un escenario dramático y teatral concreto -la muerte-, se vuelve, en extremo lúcida y objetiva, por estar situada precisamente y de tal modo en la inevitable experiencia de la muerte: ya sea en aquella sucedida en el cuerpo enfermo y moribundo asistido, hasta las últimas consecuencias, por la enfermera testigo Isla Correyero; o bien, experimentada en el propio cuerpo agónico de los enfermos terminales: Enrique Lihn y Gonzalo Millán.

Sucede así una inquietante paradoja, que permite leer estos tres textos en perspectiva. El diario de vida -que forma parte de los llamados géneros autorreferenciales o de las llamadas "escrituras del yo"-, estaría permeado por un marcado anclaje autobiográfico, lo cual supondría una mayor entrada de la subjetividad, pero resulta que, finalmente, no es tan así: estas escrituras - los diarios de Lihn, Millán y Correyero-, al estar lúcidamente situadas en la vivencia inmediata y sobre todo corporal de la muerte, se despliegan cada vez más, en tanto discursos de saber y poder sobre la mortalidad humana, como textos y/o discursos imantados por un deseo imperioso de objetividad ante el momento final, es decir, de lúcida y desvergonzada transparencia ante el punctum final de la muerte. Y he ahí que se entiende la retirada del discurso poético, es decir, de una "poesía poética" (con sus tropos transfiguradores de la realidad y de la misma muerte) y la aparición del discurso pragmático, situado de modo enfático en sus circunstancias contextuales, del diario de vida; que, como sabemos, resulta ser en estos casos extremos también una bitácora del tránsito irreversible hacia la muerte.

Se podría concluir, en este aspecto, que la muerte, en estos deslumbrantes diarios, deconstruye, de modo literal, la subjetividad del autor -a la vez que ignominiosamente va descomponiendo el cuerpo moribundo de quien escribe, en los casos de Lihn y Millán-, para que aparezca, de este modo, el "lenguaje limpio", sin metáforas: "como un cuerpo operado de todos sus órganos" (Lihn, 2015: 22); en suma, para que aparezca la nítida visión y audición del acontecer mortal, en el mismo cuerpo 
del moribundus. Sin embargo, no se trata tan sólo de dejar memoria, sino, sobre todo, de traspasar aquellas intensidades, íntimas y secretas, a la textualidad desnuda del espacio literario, a la página en blanco devenida escenario construido para la propia escenificación de la muerte propia. Hay aquí, sin duda, un gesto que conecta las escrituras póstumas de Lihn y Millán, con el proyecto siempre inacabado de una "obra abierta" al infinito y la nada, de Stéphane Mallarmé, en sus libros más jugados: Igitur o la locura de Elbehnon y Un golpe de dados. Aquel gesto consiste, pues, en hacerse de un escenario para la muerte, de construir el texto como un ensayo escénico de lo que vendrá, es decir, como un descenso preparado conscientemente para aquella disolución del ser en el absoluto de la muerte. Sin duda, será el lector, quien deba poner las cosas en escena, tal como se puntualiza al comienzo del enigmático y escénico Igitur del poeta francés: "Este Cuento se dirige a la Inteligencia misma del lector que, por sí misma, pone las cosas en escena" (Mallarmé, 2013: 201).

Es así como estos textos -en donde se presentan auténticas escenas-, devienen genuinos documentos o registros antropológicos, sociológicos, históricos y autobiográficos de la experiencia mortal, ya sea vista y sobrevivida desde la perspectiva testigo de la enfermera, la poeta Isla Correyero; o a través y desde de los cuerpos de los desahuciados escritores que escriben hasta el límite mismo de la propia vida: Enrique Lihn y Gonzalo Millán. En estos dos últimos casos, emblemáticos en la tradición de los diarios poéticos inscritos en la ominosa circunstancia de la muerte propia, parece ser que la propia vida, autobiografiada ahí en el límite de lo (in)decible, pasa a ser, paradójicamente, el pretexto -en el sentido más literal de la palabra-, de una textualidad extrema que, diríase, habla por sí misma de sí misma, sin necesidad ya de la presencia del autor, lográndose de este modo, el "milagro" de aquella "tercera persona" que el propio Lihn proyectara en su escritura, aunque sólo fuera como una utopía de su poética situada: "El lenguaje espera el milagro de una tercera persona / (que no sea el ausente de las gramáticas árabes) / ni un personaje ni una cosa ni un muerto / Un verdadero sujeto que hable de por sí, en una voz inhumana / de lo que ni yo ni tú podemos decir / bloqueados por nuestros nombres personales $(2015: 35)^{22}$.

\footnotetext{
${ }^{22}$ Obsérvese, al respecto, lo señalado por Gilles Deleuze: "la literatura [...] se plantea únicamente descubriendo bajo las personas aparentes la potencia de un impersonal que en modo alguno es una generalidad, sino una singularidad en su expresión más acabada: un hombre, una mujer, un animal, un vientre, un niño... Las dos primeras personas no sirven de condición para la enunciación literaria; la literatura sólo empieza cuando nace en nuestro interior una tercera persona que nos desposee del poder de decir Yo (lo «neutro» de Blanchot)" (1996: 8).
} 
Así, se entiende que en estas escritura de límite, donde el sujeto autorial está literalmente dejando de ser, sea ya no sólo la vida del autor el asunto o tema de la escritura, sino, mucho más allá, la vida misma de la escritura -si se permite la metáfora-, desplegándose impersonalmente desde y a partir del límite que se vislumbra en la enfermedad y en la inminencia feroz de la muerte; la que, además, le imprime velocidad a la escritura, tal como se puede ver, por ejemplo, en los diferentes estilos, ritmos y pulsiones de Veneno de escorpión azul de Gonzalo Millán. Así pues, con todo, frente a la proximidad de la última hora -la "hora-esfinge" como escribe Gilberto Triviños a propósito del símbolo de muerte, el reloj, en la obra de Federico García Lorca (Triviños, 1998)-, no queda más que el pragmatismo de la "poesía situada", o más aún, del diario de vida y muerte, aquel que impulsa a Millán a consignar obsesivamente el paso del tiempo, anotando fechas, días, horas y segundos: pues el reloj-muerte apremia y, como lo advierte el sujeto, ya no hay tiempo que perder, o bien, todo el tiempo (cada vez más preciso) solo será vivible como un "devenir intenso" y "mortal”; como el descenso (o ascenso) de la poesía en otra cosa que vendrá: música al fin, fado último en el cual se pliega finalmente, la conciencia del escritor -Gonzalo Millán-, devenido ya en otra cosa que escritor (Deleuze) $)^{23}$.

¿Fin de la poesía, entonces, e irrupción escandalosa de la confesión final del yo que escribe?... ¿O, dicho de otro modo, fin del yo autorial para que, paradójicamente, surja la verdadera, es decir, la última poesía: aquella que sólo está hecha de silencio? He ahí el espacio final de la "obra abierta” e inconclusa de Enrique Lihn y Gonzalo Millán; pero, ¿y Correyero qué?... Al final del libro de la española, se termina con un poema intitulado, donde sólo se puede leer una indicación escénica que dice sugerentemente: "Para que tú la veas"; y luego, el Diario de una enfermera se cierra así: "Se ha cerrado la puerta. Un cósmico equilibrio / desplaza las paredes / Sólo los bellos / ojos negros de Ana destiñen el azul.” (Correyero, 2014: 147).

\footnotetext{
${ }^{23}$ Me parece oportuno, en este desenlace, recordar aquí las últimas palabras de Lihn y Millán inscritas en sus respectivos diarios, pues en ellas se puede apreciar cómo el autor, transformado en personaje, prepara la escena de su disolución poética, tal como el personaje Igitur de Mallarmé. Antes cito, primero, al poeta francés: "Se acuesta en la tumba. (Título del fragmento). Sobre las cenizas de los astros, aquellas indivisas de la familia, estaba el pobre personaje, acostado, después de haber bebido la gota de nada que falta al mar. (¿El pequeño frasco vacío, locura, es lo que queda del castillo?) Partida la Nada, queda el castillo de la pureza." (Texto al margen): "o los dados - azar absorbido" (2013: 221). (Las cursivas son mías). Lihn: "Un monje misterioso / va de enfermo en enfermo con la vida en un frasco / una oscura religiosa / desovilla el ovillo de la muerte con sus manos que se dirían de ángel" (2015: 85). Y Millán: "Se jubiló el duende con mi enfermedad. Lo vi anotar algo en unos papeles arrugados. Me voy a Portugal, dijo sin mayores explicaciones. Había la voz de un fado esperando por mí”" (2007: 321).
} 
Ahora bien, observando con mayor distancia los tres diarios aquí estudiados, se puede establecer, claramente, una cierta gradualidad en el desplazamiento transgenérico desde el discurso poético hacia el discurso autobiográfico del diario de vida y muerte. En este sentido, Diario de muerte de Enrique Lihn, publicado póstumamente en 1989, es el texto que mayor cercanía conserva con el género poético y, consecuentemente, con la concepción del libro como libro de poemas o poemario (aun sabiendo que la versión fue preparada por Pedro Lastra y Adriana Valdés y que muchos de los textos no fueron titulados por Lihn). Luego de ello, en Diario de una enfermera, publicado por primera vez en $1996^{24}$, y que se acerca con más cautela a la prosa poética, es evidente la translocación del poemario en diario de vida, esto por la rigurosa y sostenida datación temporal (todos los poemas tienen su aparente fecha de redacción) y por la configuración de una voz que si bien, en general, funciona como testigo, en algunos casos se presenta como una voz decididamente confesional. En este último y fundamental aspecto, se puede observar con claridad una distancia con el texto de Lihn y con la poética impersonal que Gonzalo Millán intentara plasmar en su escritura desde sus primeros poemarios y, en especial, desde su famoso texto La ciudad, del año 1979. Este último poeta, con su experimental y multiforme diario de vida y muerte, Veneno de escorpión azul, publicado en 2007, logra apropiarse con toda naturalidad del género, alcanzando algo impensado acaso por el mismo poeta: el retorno justamente a la "relación personal" de sus primeros poemas, pero desconstruyendo, desde la misma textualidad marcadamente autobiográfica, el género del diario. Estamos sin duda, en un experimento textual profundamente liberador, que regido bajo el principio rector de la "variación" o "principio de mudanza", el autor permite la entrada de múltiples formas discursivas, dejando que la poesía deje de ser, tantas veces como sea necesario. Se podría señalar, en este último aspecto, que al fin de la vida de estos dos poetas, se encuentra finalmente el fin mismo de la poesía; o, dicho de otro modo, es lícito pensar que al final de sus diarios (y vidas), la poesía -en Lihn y Millán, pero también en Mallamé-, muere con ellos; muere con ellos, para que comience la literatura o, más precisamente, la "puesta en escena" que es la escritura literaria.

Por último, y volviendo al Diario de Correyero, es pertinente visualizar el texto, en su conjunto, como la escenificación concreta de un escenario verbal donde se vive -literalmente y de modo intenso para nuestra escritora-enfermera-, en aquella "zona

${ }^{24}$ Como se ha señalado, hay versión ampliada de Diario de una enfermera en el libro Género humano de Isla Correyero (2014), incluido en las referencias bibliográficas del presente trabajo. 
biosocial de peligro" (Elias), y que corresponde aquí al espació clínico propiamente tal. En este contexto, real e imaginario a la vez, surge la voz testigo de la enfermera quien, además de otorgar los cuidados a enfermos y moribundos, es tal puesto que $-\mathrm{y}$ de modo especial en nuestro caso-, ha abierto su corazón y su palabra al hecho semelfáctico (Jankélévitch) de ese otro ser: aquel moribundus que precisamente se desvanece ante sus ojos. Así, el trasunto ético de esta poesía clínica se despliega en ese gesto imperioso de reconocer al otro ahí, aun cuando ese otro está dejando de ser.

He ahí, entonces, el gran poder y saber de esta poesía anclada en la visión del cuerpo mortal; y con ello respondemos, en parte, a las preguntas planteadas en la "Entrada a los textos". En esta poesía el sujeto poético - enfermera devenida escritora o viceversa-, logra salir de su propio yo y deviene, en consecuencia, en un ser-para-elotro y un ser-con-el-otro, en la medida en que ha comprobado, literalmente, con sus propios ojos y con su palabra que es también memoria, cómo todo ser es, finalmente, un ser-para-la-muerte.

La muerte, en este extremo -y si se permite nuevamente la metáfora-, es una maestra para la vida: ella nos enseña que, siendo toda persona un ser-para-la-muerte, sólo nos queda entonces vivir intensamente el encuentro con ese otro: dar la vida por ese otro e incluso dar la propia muerte. Este es, definitivamente, el gran conocimiento que se esconde por los escenarios del imaginario horrible y fantasma de la clínica de Correyero. En última instancia, la enfermera sobrevive a la muerte de sus pacientes; pero siendo uno con ellos, en el "devenir intenso" (Deleuze) que se ha trazado en su poesía. Es pertinente decir entonces que ella, la enfermera-escritora, muere secretamente con sus enfermos terminales: cada día, cada noche y en cada páginaescena.

Sin duda alguna, Diario de una enfermera se puede leer como un auténtico "estudio de campo" y como un escenario concreto para aprender la muerte, tal como también, en esta perspectiva crítica, se pueden leer Diario de muerte y Veneno de escorpión azul. En ello, la poesía transita necesariamente hacia el diario de vida; y, por consiguiente, se entiende que la muerte sea una "cosa" del diario vivir y nada más.

Sin duda, estamos en presencia de un bloque de escritores; de una banda de poetas habituados a sondear las cosas del más allá o de intentar comprender el misterio pavoroso de la tumba. Dos moribundos -Lihn y Millán- tratan de escribir hasta las últimas consecuencias, con el lápiz atado a la mano y con el cuerpo herido por la fatal noticia de los "heraldos negros"; mientras, desde el otro lado, vemos a Isla Correyero, 
escribir en algún pasillo de una clínica, velando por sus enfermos terminales; encontrando ahí, en la vasta "fauna de los cadáveres" el símbolo de su propia esencia y forma de mujer: escritora, enfermera, hija, madre, amante y sobreviviente.

La gran poesía española y chilena -entendida ahora, como un gran cuerpo poético o red de conexiones subterráneas y/o rizomáticas-, deviene una misma textualidad de base ante el misterio irrepetible del Hapax por excelencia que es la muerte: las formas van variando, ciertamente, como en el libro de Millán, pero el sondeo o el pulso herido que intenta decir algo ahí, donde toda voz se desvanece, es el mismo: Rubén Darío, Federico García Lorca, Gabriela Mistral, Pablo Neruda y Vicente Huidobro; y más acá, Nicanor Parra, pero también Stella Díaz Varín y la misma Violeta Parra; y luego, desde sus danzas de la muerte, Óscar Hahn y Leopoldo María Panero; y desde sus elegías al padre muerto, Eloy Sánchez Rosillo y un joven Rafael Rubio; y, por último, a través de estos extremos y tardíos diarios poéticos de vida y muerte: Enrique Lihn y Gonzalo Millán; y, junto a ellos, una voz solitaria y fuerte: Isla Correyero.

Es posible, en definitiva, y siguiendo a Gilberto Triviños, inventariar (y escribir con) "las figuraciones de la muerte en nuestra América” o, de modo aún más específico, "iniciar la fascinante reconstrucción de un mapa latinoamericano de las ficcionalizaciones de la muerte" (Triviños, 1996: 75). Habría que decir mejor: "hispanoamericano".

He aquí, pues, que somos, humildemente, tan sólo continuadores.

\section{Telón, a modo de epílogo: ¿y el azul?...}

Un único signo aparece y reaparece a lo largo del Diario de Isla Correyero, y me vuelve a detener hacia el final de mi lectura: el azul, el color de los muertos y de la finitud. Este azul, en el Diario de Isla Correyero, no alude directamente al símbolo modernista de la poesía de Rubén Darío, de los simbolistas franceses y los románticos. No, aquí el azul es en primer lugar el color de la muerte, ese que se vislumbra en los cuerpos de los moribundos como indicio de muerte, y el cual irrumpe con su profundidad y violencia en los pálidos cuerpos de los moribundos ${ }^{25}$; el azul, que señala la muerte en el cuerpo sobre todo de ella: "Ana la azul"... "Para que tú la veas".

\footnotetext{
${ }^{25}$ No se puede omitir aquí la alusión a la "Oda a Federico García Lorca" de Pablo Neruda, en la cual el sujeto, en clave elegíaca, canta y llora por la muerte del gran poeta granadino, poema que seguramente conoció Isla Correyero: "Si pudiera llorar de miedo en una casa sola, / si pudiera sacarme los ojos y comérmelos, / lo haría por tu voz de naranjo enlutado / y por tu poesía que sale dando gritos. / Porque por
} 
Y ahí está ella: "La bella de mil años", "Ahí está, durmiendo y reclamando. Yo no sé”, "Es mi hija, mi hija adolescente", "Ahí está la niña de mil años, la flor fugaz / que no me pertenece. / Está su ropa azul y sus zapatos, su cabello / azulado de antisépticos. / Y la nariz azul y respirada por el azul de ti, / la boca toda azul, / los pechos baleados por el azul, / el sexo dividido por una raya azul, / los muslos para el azul del mar / irán. / Y los pies azules con sus uñas azules serán / para la nieve, yo lo sé.", “Ah, pero duerme mi bella ensimismada, / duerme en su experimento transparente, en su / color azul de víctima suprema", "Sólo los bellos / ojos negros de Ana destiñen el azul" (1996: 95-97).

En el fondo del azul laberinto de la clínica, que es también un espacio y un cuerpo, se encuentra ella: "Ana la azul”. Ella habita en el centro del laberinto, en la matriz azulada del vientre de la madre - de la propia escritora Isla Correyero, puesto que se trata de un diario de vida y muerte- ${ }^{26}$. "Ana la azul" habita en la memoria del cuerpo y del libro; y solo sus ojos negros, los cuales vuelven a abrirse ante la última mirada del sujeto de esta poesía, pueden resistir el avance silencioso de la muerte que, como el mar, sumerge todo en el más profundo de los olvidos.

La utopía del "pueblo que falta" -siempre inacabado y en constante devenir-, se proyecta aquí a través de la búsqueda de un espacio ritual y simbólico -aquí el espacio literario del texto- donde es posible el tránsito y acaso el soñado encuentro de los vivos y los muertos. El "espacio fantasma" de la clínica es, de este modo, más que un escenario de muerte, un escenario de resistencia, donde la vida se afirma aún ante la

ti pintan de azul los hospitales / y crecen las escuelas y los barrios marítimos, / y se pueblan de plumas los ángeles heridos, / y se cubren de escamas los pescados nupciales, / y van volando al cielo los erizos: / por ti las sastrerías con sus negras membranas / se llenan de cucharas y de sangre / y tragan cintas rotas, y se matan a besos, / y se visten de blanco." (2010: 146). Por otra parte, es posible asociar también el color azul claro (así como el verde azulado) con las paredes de ciertos hospitales o clínicas y más aún, con los uniformes de los cirujanos y la demás indumentaria textil usada en dichos recintos, pues estos colores se oponen, significativamente, al color rojo de la sangre. En el contexto hospitalario y/o clínico, el uso de estos colores tendría una función tranquilizadora, para la vista, tanto del paciente como del cirujano enfrentado a una operación o intervención quirúrgica. De este modo, el color azul claro tendría un uso más bien funcional. También, en ciertos hospitales y clínicas es común el pintado de una franja de estos colores, en las paredes de los pasillos, lo cual podría señalar una dirección a seguir en el espacio (laberíntico) del hospital. Ahora bien, refiriéndonos al diario de Isla Correyero, es posible sostener, además de todo lo anterior, que el azul claro tiene una función indicial que señala directamente a los enfermos y luego a los cadáveres en donde el proceso de descomposición (o tanatomorfosis) es inminente. Es sugerente el hecho de que la portada del libro de la poeta sea azul claro y que en ella aparezca un laberinto.

${ }^{26}$ Me refiero aquí a la imagen de la serie Laberintos de Jq. Ruiz Millet y Ana Planella, que aparece en la portada del libro de Isla Correyero (1996), y que aporta profundas significaciones a la lectura del poemario, especialmente en torno a los simbolismos del azul y del laberinto. 
evidencia atroz e irremediable del destino humano mortal. En este contexto, se entiende que el propio lenguaje -aquí el lenguaje poético del diario-, es "la vida que lleva la muerte en sí y en ella se mantiene", pero "la literatura empieza por el fin, lo único que permite comprenderla. Para hablar debemos ver la muerte, verla tras nosotros" (Blanchot, 2006: 65). Y esto es también válido para los tres autores aquí estudiados: Isla Correyero, Gonzalo Millán y Enrique Lihn.

De este modo, escribiendo, la enfermera Isla Correyero, resiste el dolor y el olvido, quizás la forma más extrema y total de la muerte; y con ello la escritora, heroína frágil, pero heroína al fin, adquiere esa "pequeña salud”, la cual le permite sobrevivir a la muerte de los otros, convirtiendo, de este modo, el intolerable estremecimiento en relato... ¡La muerte en diario de vida!

\section{Bibliografías}

Barley, Nigel. Bailando sobre la tumba. Barcelona: Editorial Anagrama, 2005.

Blanchot, Maurice. De Kafka a Kafka. México D. F.: Fondo de Cultura Económica. 2006.

Contreras, Marta. Griselda Gambaro. Teatro de la descomposición. Santiago, Chile: Logos. 1994.

Correyero, Isla. Diario de una enfermera. Córdoba, Argentina: Huerga y Fierro Editores, 1996.

Correyero, Isla. Género humano. Madrid: Inspirar-Expirar Ediciones. 2014.

Deleuze, Gilles. Crítica y clínica. Valencia: Pre-Textos. 1996.

Elias, Norbert. La soledad de los moribundos. México D.F.: Centzontle, Fondo de Cultura Económica. 2009.

Galindo, Óscar. "Mutaciones disciplinarias en la poesía de Enrique Lihn". Revista Estudios Filológicos 37. (2002): 225-240.

García Canclini, Néstor. Culturas híbridas. Estrategias para entrar y salir de la modernidad. Barcelona: Editorial Paidós. 2001.

Jankélévitch, Vladimir. La muerte. Valencia: Pre-Textos. 2009.

Lihn, Enrique. Diario de muerte. Santiago, Chile: Editorial Universitaria. 1989.

Lihn, Enrique. Diario de muerte. Santiago, Chile: Ediciones Universidad Diego Portales. 2015.

Lihn, Enrique. Porque escribí. Santiago, Chile: Fondo de Cultura Económica. 1996.

Mallamé, Stéphane. Obra poética. Buenos Aires, Argentina: Colihue, 2013.

Mendoza, Tulio. "Isla Correyero: la deslumbradora oscuridad de la desesperación". Diario El sur, Concepción. 15 de oct de 2014.

Millán, Gonzalo. Veneno de escorpión azul. Santiago: Ediciones Universidad Diego Portales. 2007.

Neruda, Pablo. Antología general. Madrid: Santillana Ediciones Generales, 2010.

Ostria, Mauricio. "El espejo roto. Notas sobre la poética de Enrique Lihn". Contra el canto de la goma de borrar: asedios a Enrique Lihn. Coord. Francisca, Noguerol, Sevilla: Secretariado de Publicaciones, Universidad de Sevilla. 2005. 
Ostria, Mauricio. "Enrique Lihn o la desdicha sin respuesta". Revista de crítica literaria latinoamericana, año XVIII. 35 (1992): 49-60.

Rodríguez, Mario. "Diario de muerte de Enrique Lihn: El deseo de la escritura". Revista Acta Literaria, 18 (1993):25-36.

Sontag, Susan. Contra la interpretación. Barcelona: Seix Barral. 1984.

Triviños, Gilberto. "Las metamorfosis de la Muerte semejante a Diana en la poesía de Rubén Darío, Vicente Huidobro y Nicanor Parra”. Revista Acta Literaria, 21 (1996):75-92.

Triviños, Gilberto. "La visión del último rostro en la obra de Federico García Lorca". Revista Acta Literaria, 23 (1998):9-30. 